果を示した。然し多量の混大の䇡合は $\mathrm{Al}$ の埸合と同樣に何れの 坊合も不良となり，又Si は他二者に比し效果が低い。

\section{4. 實驗結果の考察}

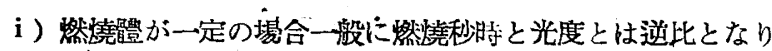
照度比X秒時は一定となるべきであるが，特間が延長すると溫度 低下によつて光度は急激に減少する。

ii ) $\mathrm{Ba}\left(\mathrm{NO}_{3}\right)_{2}$ の一部を $\mathrm{KNO}_{3}$ で置换すると蝳燒中絕現象な く，時間がよく延長するのは $\mathrm{KNO}_{3}$ の䓡分解速度が絵慢で融點 以上の溫度で $\mathrm{O}_{2}$ を徐々に發生するのに反して, $\mathrm{Ba}\left(\mathrm{NO}_{3}\right)_{2}$ が频 融と同時に爆發的に $\mathrm{O}_{2}$ を出すためと考えられる。

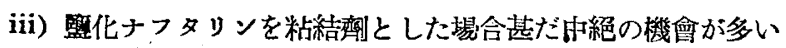
のはハロゲンの逨鎖反應を斷ち切る作用が大きな原因であろう。

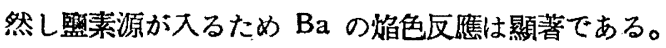

iv）再生アルミニウムを便用した時燃然し難いのは活性化され た部分が甚だ少いことを示すものであろう。然し暨化ナフタッン

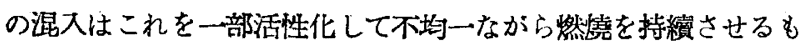
のであろう。

v) $\mathrm{CaSi}_{2}$ 又は $\mathrm{FeSi}_{2}$ 混入が艮好な影響を與えるのは $\mathrm{Ca}$ 又

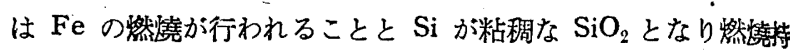
續に必要な䓡量を絕えず未絔燒部分に傳えるためでないかと考え る。撘融狀態の $\mathrm{SiO}_{2}$ が煙となつて飛散すべき酸化物を捕えるこ とは然燒残查の分析又は $\mathrm{CaSi}_{\text {。 }}$ や $\mathrm{FeSi}_{2}$ の混入が多いと生成し

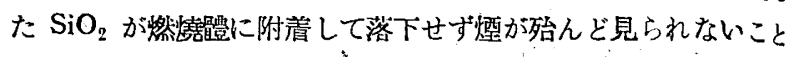
によつても分る。

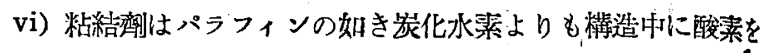
含むもの>方が良いと考えられるが炭水化物は不艮であつた。

一vii） $\mathrm{Mg}$ 。を用いた埸合は $\mathrm{Al}$ のときょり相對的に长好な結果を 示すことは論をまためが， $\mathrm{CaSi}_{2}, \mathrm{FeSi}_{2}$ 等の影響は $\mathrm{Al}$ の埸合 と全く同栐である。

\section{5. 總括}

$\mathrm{Ba}\left(\mathrm{NO}_{3}\right)_{2}$ を酸素供給體として $\mathrm{Al}$ を燃燒させる場合, $\mathrm{Al} の$ 一部を $\mathrm{CaSi}_{2}, \mathrm{FeSi}_{2}$ で, $\mathrm{Ba}\left(\mathrm{NO}_{3}\right)_{2}$ の一部を, $\mathrm{KNO}_{3}$ で踢換せ るものについて筫驗を行い，撚燒の均一，時間の延長等に於て鸟 好な結果を得た。粘着劑としては炭化水素よりも酸絜の入つたも のが好結果を得た。 $\mathrm{Mg}$ を用いた埸合は $\mathrm{Al}$ の場合より昼好で， $\mathrm{CaSi}_{2}, \mathrm{FeSi}_{2}, \mathrm{KNO}_{3}$ 紫の影響は $\mathrm{Al}$ の場合と全く同じであつた。

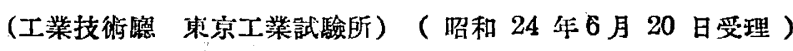

\title{
（51）寫眞乾板の超增感處理に就て
}

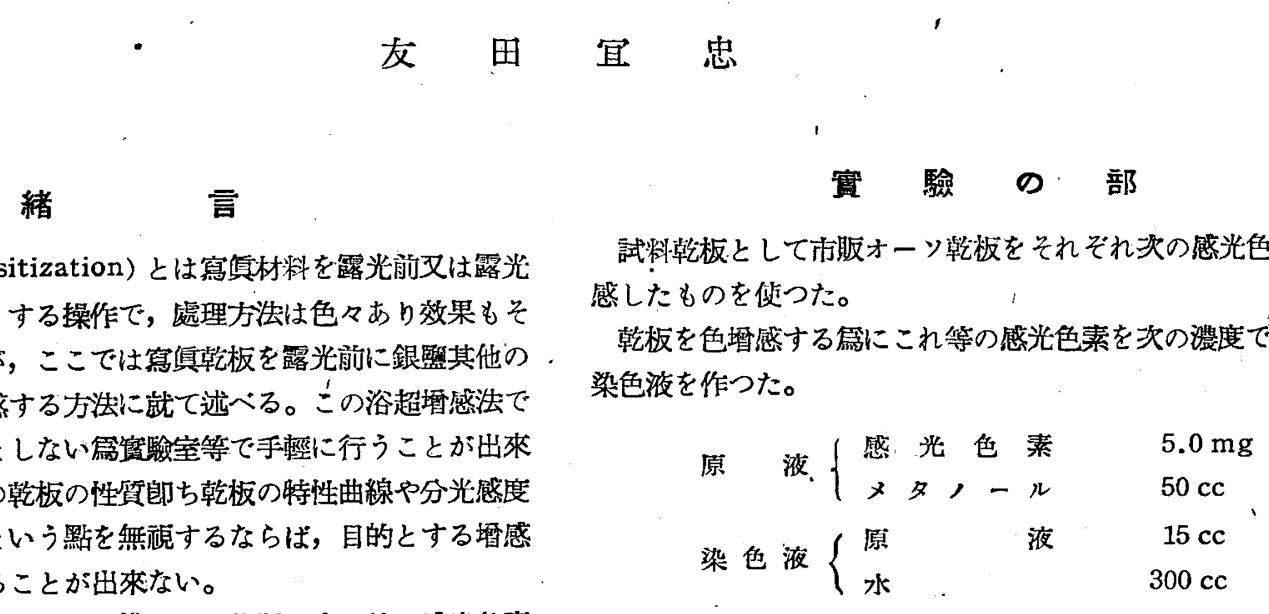

又, 浴超増感に於ては乾板を構成する物質の中で特に感光色素

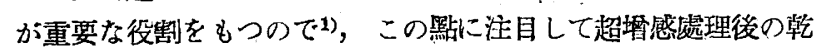
板の特性曲線と分光感度とをしらべたので報告する。

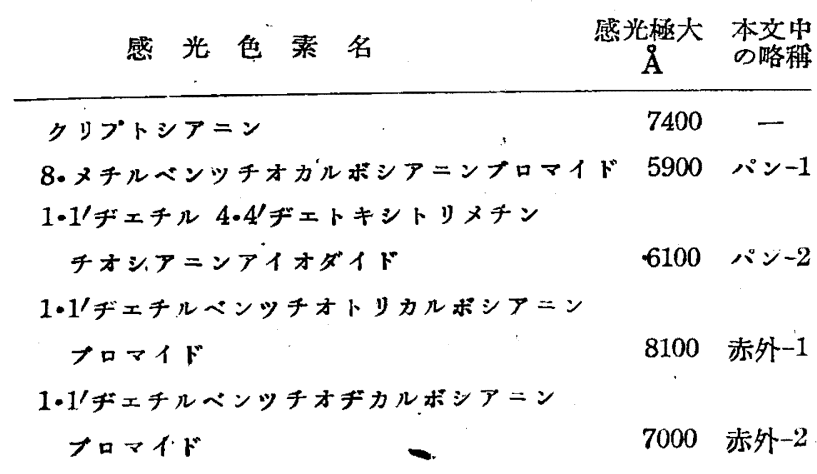

液涩を $18^{\circ} \mathrm{C}$ とし，就料乾板を 3 分間浸漬して後乾燥する。 次にこの乾板を超墂感するのであるがこうでは次の 4 種類の 方法を探つた。

1. 水洗法：試料を $18^{\circ} \mathrm{C}$ の蒸溜水に 10 分間浸漬

2. ピリヂン法：試料を $1 \%$ のピりデン水溶液に $18^{\circ} \mathrm{C} て ゙ 10$ 分間浸婊

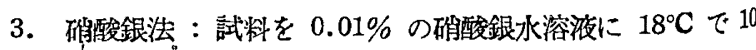
分間漫清

4. タングステン酸銀法：アンモニア性タングステン酸銀水 溶液（銀イオン濃度約 $0.1 \mathrm{~g} /$ l) に試料を $18^{\circ} \mathrm{C}$ で5分間浸㳻。 以上何れの處理に於ても浸漬後試料をアルコールに1分間浸清し て直ちに湀風乾燥した。

フロマイド 7000 赤外-2

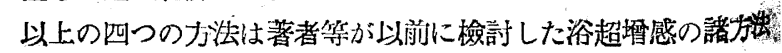


第 1 阔
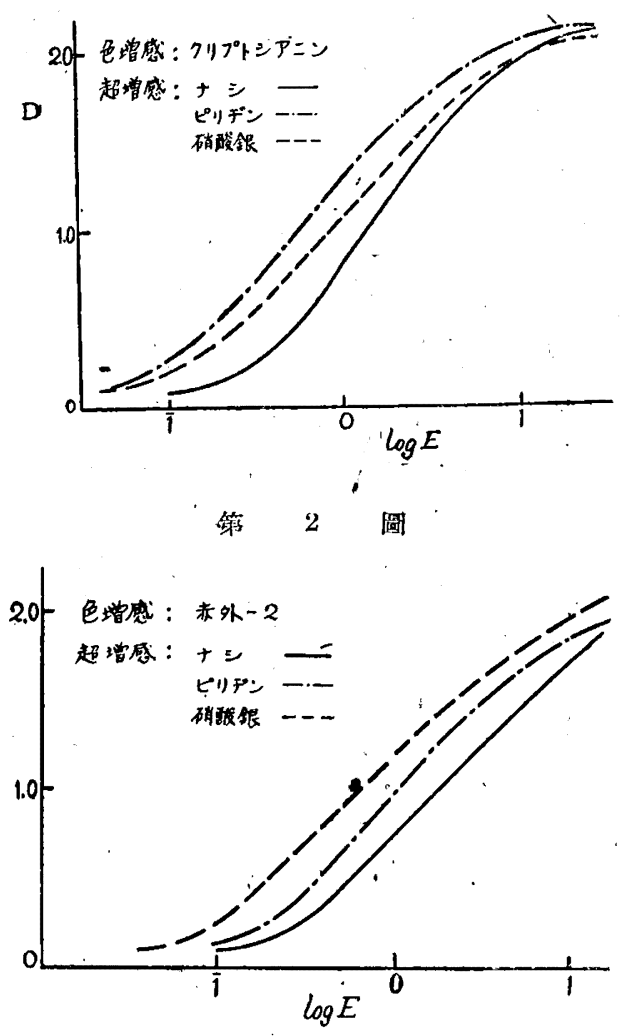

第 3 四

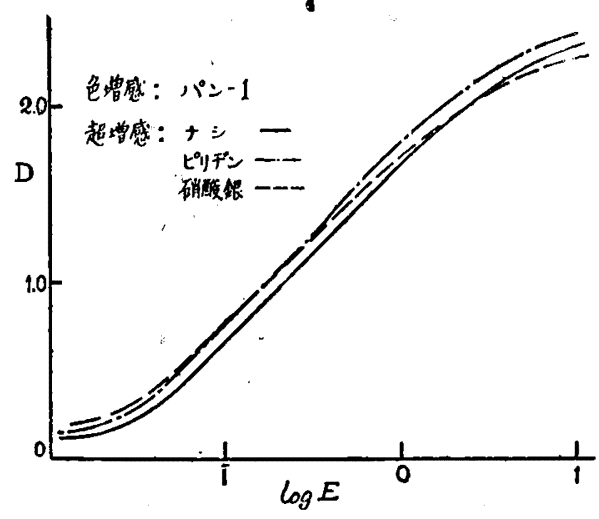

第 4 圖

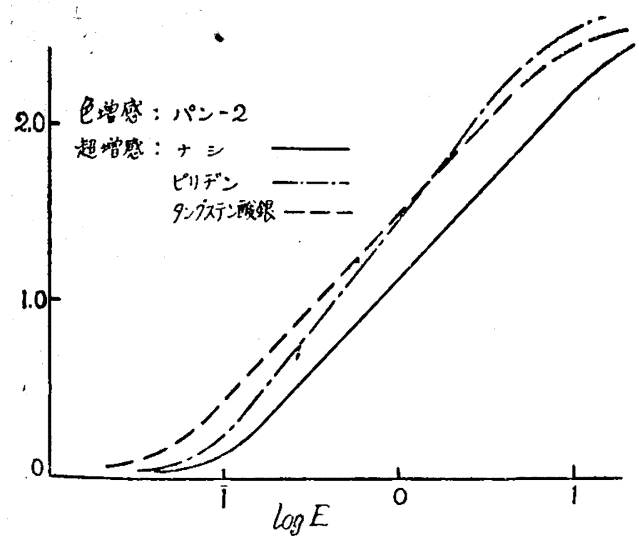

第 5 圆
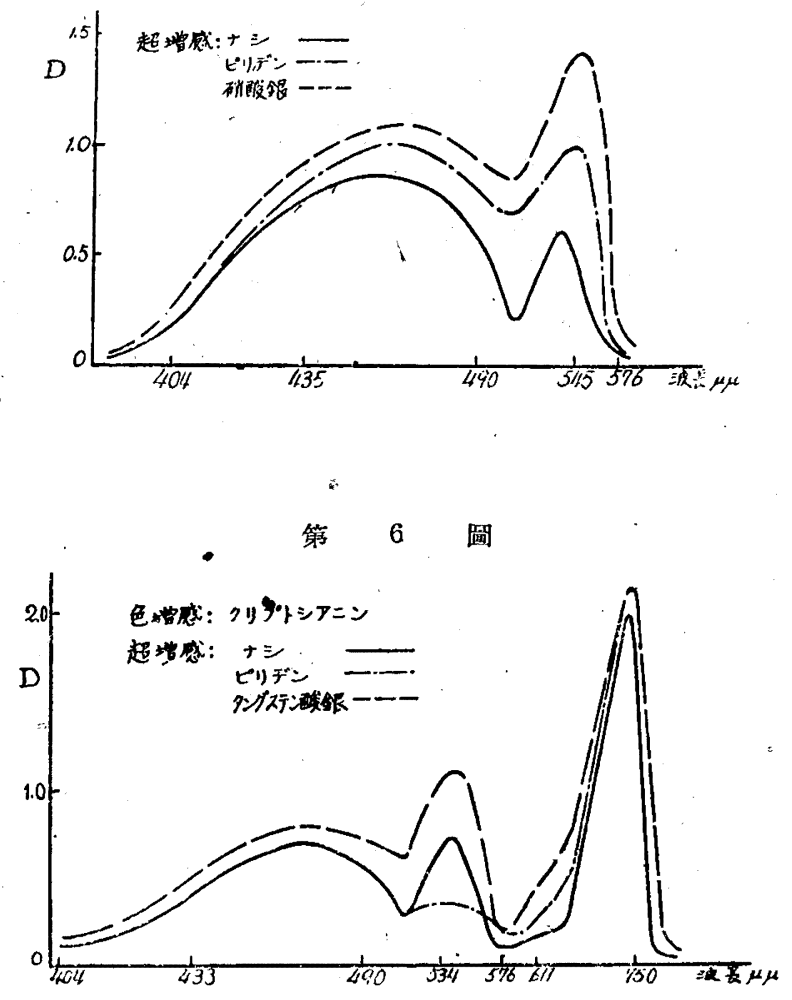

第 7 四

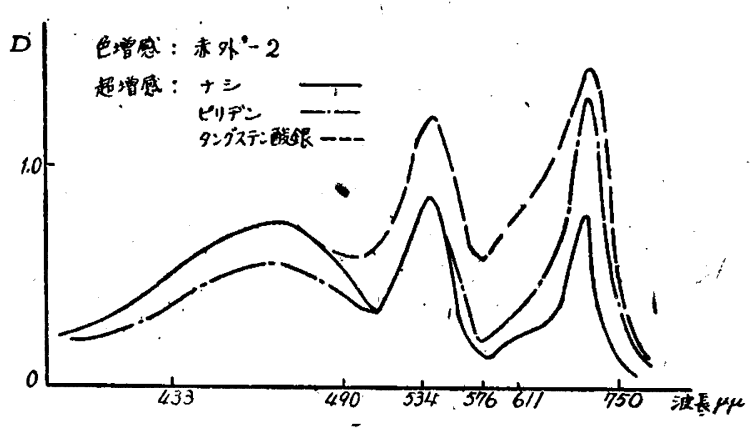

第 $8^{\circ}$ 圆

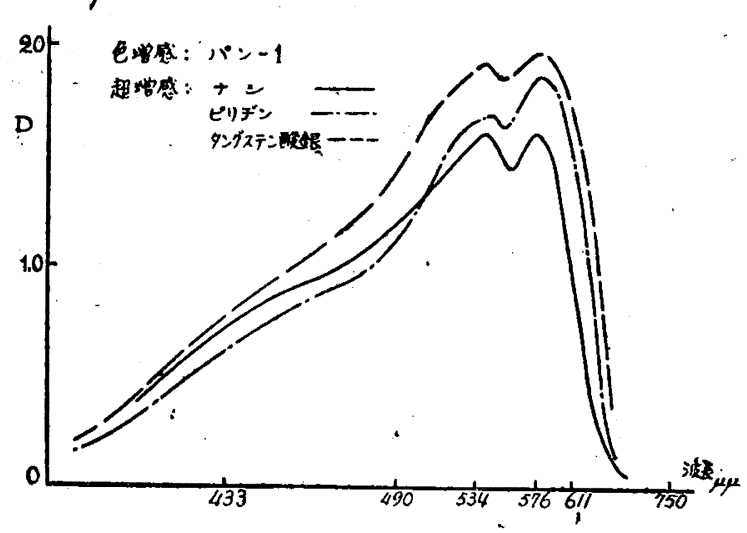


の恬で代表的なものと考えられ，且多くの試料乾板に對して垍感 可能なことが期街されるものである。又，これ等のお法の中，砣 酸銀法とタングステン酸銀法とを銀㹂水溶液を使用するという點 で同一視すればこれは水洗法やピリデン法と㙼感機棈も暴ると 考えられるのでこ〉に取上げたわけである。包上の 4 方法に於け る處理條件，郎ち溶液の濃度，浸漬時間，液溫度等に就ては既に 發表したので省略する22。

超極感處理試料の特性曲線を求める篇の感度测定は，主として 感度の比較値を考えればよいので，タングステン電球を 1.2 燭光 で點じて光源とし，これから $50 \mathrm{~cm}$ の距離に於て濃㢑差 0.1 の 階段梆（微小部濃度計で補正）を當てた試料乾板に 20 秒の露光 を與えた。これをメトーれ $2 \mathrm{~g}$ ，無水亞硫酸ナトリウム $50 \mathrm{~g}$ ， 八 イドロキノン $8 \mathrm{~g}$ ，無水炭酸ナトリウム $30 \mathrm{~g}$ ，具化カリウム $2 \mathrm{~g}$

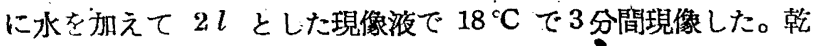
板の濃度は山部式濃度計で測定して特性曲線を得た。その1部を 第 $1 \sim 4$ 圖に示した。

又，乾板の分光感度を測定するには試料乾板で理研定偏角型分 光器により分光竄臭撮影を行い，前記現像液で現像し，黑化濃度 を各波長に就て微小部濃度計で湘定した。第 5 ～圆は結果の一 部で，黑化湢度と波長とを兩軸にとつた。乾板の分光臨度を表現 寸る䈔には各波長別に特性曲線を求めねばならないのであるが， 本報ではそこまで及ばなかつたので，感度を定性的に知ることし か出來ない。

先ず特性曲線に就ては次の事が結論される。

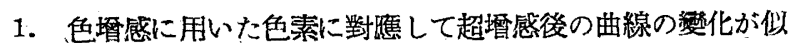
た傾问をとる。例えば第 1 圖のクリプトシナニンで色堙感した試
料では露光量の少い側で超僣感效果が著るしく，第 3 圖のパンク 口色恓感された乾板では殆ど超堶感されない。

2. 次に超唒感法の種類によつて特性曲線の推移が特徽を示し

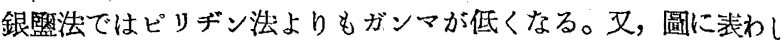
てないが，碓酸銀法とタングステン酸銀法とでは殆ど同一の結集 を與える。

次に分光的觀測の結果から次のことが結論される。

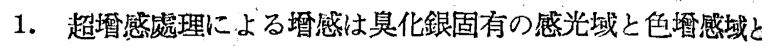
に分けて考えられる。何れの場合も感光極大の位置は殆ど變化か ない。

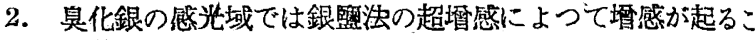
そが多く，ピリヂン法では殆ど增感されず，却つて減感している 場合も少くない。

3. 色壖感域に現われる超墂感の效果は，その慓感色素と超增 㥿法の種類によつて區アで一般的に述べられない。

總括

オーソ乾板を色樰感して後超堙感した際の乾板の特性曲線及び 分光的感度の變化をしらべた。，その結果，乾板を色堙感した感光 色素が超墂感結果に重要な影響を與えることが分つた。

本犐充で使用した感光色素の一部は富士篦區フィルム株式會神 の研究所から戴き；又筫驗は長谷川登美子氏の助力によつて行わ れた。こてに兩渚に厚く謝意を表する。 一引用文践一

1) 菊池，友田，日鼠，10，120 (1947)

2) 菊池, 友田, 日窞, 10, 50 (1945)

（名古屋大祭工學部應用化學教室）（昭相 24 年 7 月 7 日受理）

\section{（52）砣酸監に關する研究（第 4 報） 酸化アルミニウム一五酸化破素一水 3 成分系の平衡に就て}

高橋武彥・佐々木熊三

\section{緒言}

先に發表した第2報に於て，砒酸アルミニウムを䨋解によつて 製造する方法につき，その諸條件を檢討した。この龟解に於て， 、電解腹中に存在せしめた砣酸の濃度は，比較的低い場合であり， その際 $\mathrm{Al}_{2} \mathrm{O}_{3}: \mathrm{As}_{2} \mathrm{O}_{5}=1: 1$ (モル比)の中性監が得られることを 報告した。しかし砣酸の裖度を高くした埸合に，如何なる形の砒

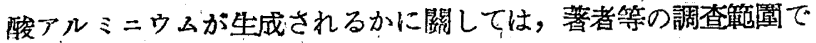
は參考となるべき交㱆が見當らない。常識的に考えられるのは，

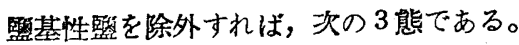

1) $\mathrm{Al}_{2} \mathrm{O}_{3}: \mathrm{As}_{2} \mathrm{O}_{5}=1: 1$ (モ儿比)

2) $\mathrm{Al}_{2} \mathrm{O}_{3}: \mathrm{As}_{2} \mathrm{O}_{5}=2: 3(" /)$

3) $\mathrm{Al}_{2} \mathrm{O}_{3}: \mathrm{As}_{2} \mathrm{O}_{5}=1: 3(" /)$

これ等にそれぞれ結晶水が結合し，各樣の䂤酸アルミニウムを 形成すると考えられる。而してこれらが常識通りの形をとるか否
か，又その結晶水は如何，等を決定するために揭題の平衡を $30^{\circ} \mathrm{C}$ に於て測定した。中性䤃として

$$
\mathrm{Al}_{2} \mathrm{O}_{3} \cdot \mathrm{As}_{2} \mathrm{O}_{5} \cdot 16 \mathrm{H}_{2} \mathrm{O}
$$

の形のものが天然に崖することが報告されており，これは Liskeardite と呼ばれている。

\section{寞 驗方 法}

酸化アルミニウムそのま〉の形では吪酸と反應し難く画驗に用 うることはできない。文水酸化アルミニウムの形に於ても，その 表面のみ反應し內部は水酸化物のま〉殘る傾向があり，本衡に達 する迄長時間を要する不溉がある。よつて著者等は正砣酸アルミ ニウムを被め㱔造し，これを種々の濃度の砒酸水溶液に反應せし

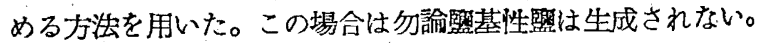

1）正砒酸アルミニウムの製法、吪酸ソーダと硫酸アルミニウ ムとの反應によつた。この場合，水酸化アルミニウムの共沏を防 